Carlos Camponez

Ana Teresa Peixinho

Coordenação

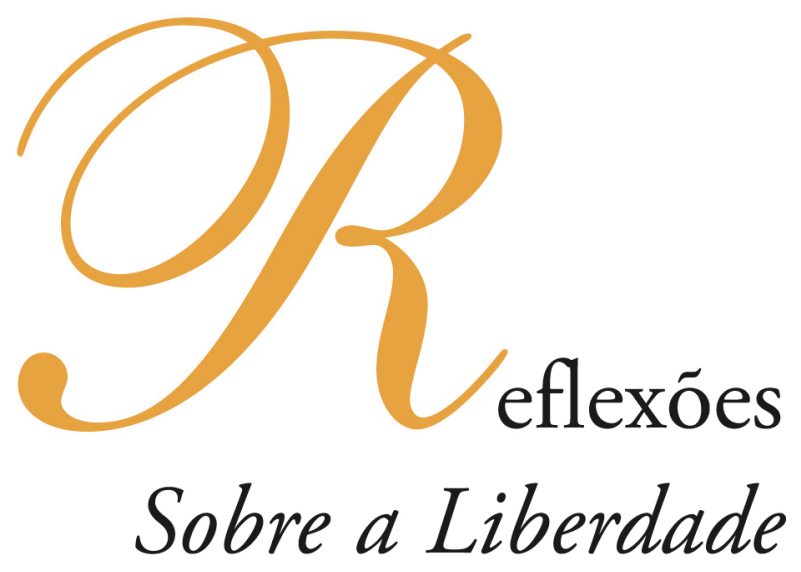

150 anos da obra de John Stuart Mill

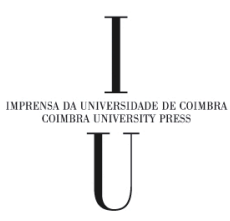




\section{INTRODUÇÁO \\ LIBERDADE: UM VALOR EM CONSTRUÇÃO}

Carlos Camponez

\section{Ana Teresa Peixinho}

As ideias não são meras abstracções. A História está repleta de exemplos sobre o poder de as ideias se imporem como acontecimentos transformadores, capazes de criarem novas mundividências, a partir das quais o Homem se recria e reinventa o mundo à sua volta. Se tivéssemos de escolher uma de entre as mais poderosas ideias transformadoras da História, talvez fosse justo eleger a Liberdade. Ela encerra, no seu seio, a maior revolução que a humanidade levou a cabo ao longo da sua existência e é certamente o legado mais importante dos últimos quatro séculos às geraçóes vindouras. A Liberdade constituiu-se nessa vaga de fundo que, no turbilhão das suas águas, rebentou as amarras que permitiram soltar o poder criador do género humano, que esteve na base do progresso técnico, científico, económico, político e cultural. A Liberdade deu origem às grandes revoluçóes encetadas pelo homem ao longo da sua História e sem a qual não seria possível compreender a evolução das sociedades humanas.

Perante tấo importante conceito mobilizador do pensamento e da História, o Departamento de Filosofia, Comunicação e Informação da Faculdade de Letras da Universidade de Coimbra decidiu, a propósito da comemoraçáo dos 150 anos da publicação do livro de John Stuart Mill Sobre a Liberdade, contribuir para retomar uma reflexão que, por mais inesgotável que seja, nem por isso se revela menos importante e decisiva. Deste modo, a 10 de Dezembro de 2009, organizou um colóquio sobre John Stuart Mill, com o objectivo de reunir um conjunto de contributos interdisciplinares que trouxessem novas reflexóes sobre uma das obras emblemáticas daquele que é considerado um dos mais importantes filósofos britânicos do séc. XIX.

Este colóquio construiu-se com contributos de várias áreas científicas, nomeadamente do Direito, da Filosofia, da Comunicação e da Ciência Política. Foi um intenso dia de trabalho e de reflexão, em que foram proferidas sete conferências, muito diversas quer nos temas, quer nos enfoques, mas cujo mote comum foi a celebração do aniversário da célebre obra de Stuart Mill. Este livro é, como tal, fruto dessas contribuiçóes e pretende levar ao público várias reflexóes em torno de um autor incontornável, Stuart Mill, e de um conceito sempre actual, a Liberdade.

No presente texto de introduçáo, mais do que uma mera exposiçáo dos trabalhos apresentados nesse colóquio, traçaremos um percurso de revisitação guiado pelo tema da Liberdade como motor das sociedades e, simultaneamente, como um projecto sempre inacabado. Esta opção sustentará a releitura dos textos aqui propostos, assumindo a Liberdade na sua dupla dimensão de legado e de desafio.

Por um lado, um legado de geraçôes, construído tantas vezes - não é demais recordá-lo com o sangue dos que padeceram nas masmorras da Inquisição, nas praias da Normandia, nos goulags siberianos ou nas celas de tortura dos prisioneiros políticos.

Por outro lado, a Liberdade apresenta-se-nos como um desafio - e é a esta dimensão que daremos aqui especial relevo. Com efeito a Liberdade nunca se nos apresentará como uma conquista definitiva, mas tão-somente como um trajecto cujo caminho é necessário desbravar todos os dias. Trata-se no fundo de uma viagem milenar, que acompanha a evo- 
lução do homem e que o faz desejar a utopia, sonhar, criar e criar-se. Para além disso, é também, uma viagem perpétua, com obstáculos, armadilhas e resistências. Como parece ter percebido muito bem John Stuart Mill, e as leituras sobre o autor póem-no em relevo neste livro, a natureza deste desafio coloca-se numa dupla dimensão: como algo em constante construção; e como um conceito que não está livre de, ele próprio, ser aprisionado pelas lógicas dos poderes do momento.

Em primeiro lugar, o entendimento da Liberdade como um processo constante de construção é ele próprio fundador da ideia de Liberdade. Este legado que recebemos das geraçôes que nos antecederam apresenta-se-nos como algo eternamente inacabado e aí reside a natureza do desafio das geraçôes contemporâneas. Essa realidade é-nos apresentada permanentemente pela constante mobilidade das fronteiras da Liberdade. Bastará para isso recordar o alerta inquietante lançado pelo Freedom House, um grupo de pressão norteamericano com sede em Washington que, no seu relatório de 2010, refere que há quatro anos consecutivos que a Liberdade e os Direitos Humanos estão em regressão em todo o mundo. Segundo ainda o relatório, nas quase quatro décadas em que aquela organização começou a fazer estes estudos, esta é a primeira vez que uma tal regressão das liberdades e dos direitos dos cidadãos se verifica por um período tão alargado.

Fenómenos como a crise económica ou o combate aos terrorismos poderão ajudar-nos a explicar a razão pela qual estejamos hoje mais abertos a admitir a diminuição das fronteiras da Liberdade. Mas como nos recorda Manuel Alegre, a esse facto não será alheia a própria crise de valores das sociedades contemporâneas que se reflecte, nomeadamente, nas suas formas de representação e de confiança mútua.

Manuel Alegre, dada a sua experiência vívida e vivida de privação de Liberdade, vem recordar-nos que não é possível falar dela sem discutir também as formas concretas da sua realização. Por isso, o tema das desigualdades parece ser tão sensível no mundo contemporâneo, marcado pelo crescente fosso entre ricos e pobres. Na verdade, não é coincidência que, em Sobre a Liberdade, Stuart Mill também se tenha inquietado com o aspecto tão arrasador das desigualdades, como sublinha no seu texto Maria João Silveirinha.

Se as desigualdades sócio-económicas, sublinhadas por Alegre, desembocam na privação de Liberdade, as assimetrias de género também são um problema actual que se arrasta há séculos e é responsável por um perigoso desequilíbrio social. A profunda injustiça da situação da mulher em meados do séc. XIX talvez explique a razão pela qual John Stuart Mill tenha sido bem mais sensível à urgência do reconhecimento da igualdade dos direitos entre géneros no espaço público, do que ao estatuto profundamente desigual da mulher no espaço privado, da família e do ambiente doméstico, normalmente suportado no preconceito acerca da sua «natureza» de progenitora e, "por consequência», de ser particularmente dotado de sensibilidade.

Se tivéssemos que demonstrar quanto há de político na «natureza» e nas relaçóes privadas entre sujeitos, esta seria, certamente, uma eloquente base de partida para o fazer. Tanto o argumento em defesa da igualdade da mulher como o reconhecimento da sua diferença podem ser objecto de apropriação pelos discursos mais progressistas como pelos mais conservadores, como a reflexão feminista já percebeu há bastante tempo. O que a nosso ver parece evidente é que o reconhecimento da diferença das mulheres como elemento integrante da sua emancipação só pode realizar-se plenamente quando estiverem asseguradas, à partida, as condiçóes de igualdade. 
A igualdade é, de resto, um tema recorrente que os críticos nunca deixarão de recordar aos liberais. Manuel Alegre fê-lo a propósito de Mill, considerado uma das traves mestras do Liberalismo, ainda que pelo seu pensamento nunca tivesse passado a ideia de um laissez faire laissez passer como mecanismo exclusivo de regulação das sociedades, do qual o Estado deveria estar completamente arredado. Esta questão é particularmente sensível, em especial no campo da liberdade de expressão e da liberdade de imprensa. Como nos recorda Carlos Camponez, evocando o estudo do investigador esloveno Slavko Splichal, em particular no que se refere à liberdade de expressão e à liberdade de imprensa, o livre mercado das ideias muito dificilmente pode ser atribuído a Mill como é comummente aceite dentro de uma certa tradição liberal. Com efeito, Mill, na senda de Tocqueville, pressentiu os perigos que as democracias de massa e os espaços de opinião pública mediatizados poderiam ter para a liberdade de expressão, silenciando as vozes da diferença. Por isso, Mill não foi um entusiasta das potencialidades da democracia, a curto prazo. Também por isso, percebeu que o mercado das ideias e das opinióes maioritárias não é necessariamente espaço de progresso da verdade, como de resto está profusamente demonstrado na história das ideias. Tanto a Liberdade como a verdade têm em comum o facto de permanecerem, qualquer que seja o seu estádio, num projecto inacabado. Reinterpretando José Tomaz Castello Branco, diríamos que a tolerância é a consciência de que existe algo de precário, de incerto e de inacabado na Liberdade e na verdade.

Assim, a liberdade de expressão surge de forma tão sensível como projecto de realização dos indivíduos, mas também das próprias sociedades, na medida em que lhe for permitido, mesmo enquanto opinião minoritária, desempenhar um papel crítico e suscitar uma discussão socialmente vibrante. Se o facto de a diversidade rimar com liberdade pressupuser uma ligação intrínseca entre os dois conceitos, como parece entender Manuel Alegre, então estaremos perante um dos desafios cruciais que se colocam hoje à liberdade de imprensa. No seu ímpeto de responder ao suposto desejo das audiências, num contexto de mercado das ideias, o campo dos media tem-se transformado num poderoso instrumento de uniformização, não obstante a sua pluralidade. No ruído de vozes que se cruzam no espaço público mediatizado, os media asseguram a pluralidade das ideias, sem com isso garantirem necessariamente a diversidade de opinióes.

Esta consciência é premente nas sociedades ocidentais actuais mas esteve já presente na intelectualidade do século XIX. Entre nós, um escritor e homem de letras como Eça de Queirós deixou testemunho dessa sensibilidade em páginas da imprensa do tempo e em cartas a camaradas geracionais. Num conhecido prefácio a Azulejos do Conde de Arnoso, publicado sob a forma epistolar em 1886, afirma:

«Essa coisa tấo maravilhosa, de um mecanismo tão delicado, chamada o indivíduo, desapareceu; e começaram a mover-se as multidóes, governadas por um instinto, por um interesse ou por um entusiasmo. Foi entáo que se sumiu o leitor, antigo leitor, discípulo e confidente, sentado longe dos ruídos incultos sob o claro busto de Minerva, o leitor amigo, com quem se conversava deliciosamente em longos, loquazes «Proémios»: e em lugar dele o homem de letras viu diante de si a turba que se chama o público, que lê alto e à pressa no rumor das ruas».

Esta é também uma das questôes centrais da abordagem que José Tomaz Castello Branco faz na sua reflexão sobre o livro de Mill, ao salientar a importância que as noçóes de 
Liberdade e de tolerância desempenham no seu pensamento. Com efeito, para que a liberdade de expressão seja possível, ela só é realizável um contexto de tolerância. Mas uma tolerância que não seja apenas entendida, tal como no-la descreve o Padre António Vieira, como o sermáo de Santo António que, perante o ostracismo e a surdez dos homens, não teve outra alternativa do que ir pregar aos peixes. De facto, para que a tolerância se possa exercer na sua plenitude, ela deve permanecer como um espaço de «racionalidade crítica»e não apenas como um lugar inconsequente, onde grassa o relativismo, a indiferença e a paz podre do conformismo. A liberdade de expressão num contexto de racionalidade crítica é o espaço que garante a realização dos sujeitos e o progresso das sociedades. Daí a ênfase colocada na Liberdade como poder da palavra: «a poesia é o poder» - dizia Osip Mandelstan, citado por Manuel Alegre. Nesse sentido, talvez fosse oportuno recordar Albert Camus, quando sobre a imprensa dizia que, livre, a imprensa poderia ser boa ou má, mas sem liberdade ela só poderia ser má. Cremos que o mesmo se poderá aplicar às sociedades contemporâneas: sem liberdade de escolha, de opinião e de expressão, só poderemos esperar, a breve trecho, o seu amesquinhamento progressivo.

Este aspecto remete-nos para o segundo ponto que gostaríamos de sublinhar. Se até aqui enfatizámos os aspectos relacionados com a Liberdade como construção contínua, como realização dos sujeitos, como poder da palavra e como condição de progresso da verdade, importa também sublinhar que a ideia de Liberdade como projecto inacabado nos chama a atençáo para o facto de existir nela algo de imperfeito e de nem ela própria estar a salvo dos discursos manipuladores com objectivos ínvios ao seu próprio ideal. Deste modo, considerar a liberdade como um projecto inacabado e um desafio sempre renovado afigurase-nos em si mesma uma ideia libertadora, na medida em que, deste modo, se impede que, na sua procura da perfeição, o Homem se deixe enredar na ilusão de um modelo definitivo de organização social, perante o qual não lhe restaria outra alternativa se não a da sua submissão. Isso mesmo esteve presente nas tentativas de construção das sociedades sem classe e, ironicamente, não deixou de ser sugerido nas ruínas do muro de Berlim, através da ideia que estaríamos a chegar ao Fim da História. Perante esta ideia finalística, o homem estaria à beira de esgotar as suas possibilidades de se pensar, submergido pelo poder de um modelo vencedor e único de realização social.

Com efeito, muito antes de nós, já, pelo menos, os iluministas e os revolucionários franceses perceberam que, mesmo enquanto vaga de fundo, a Liberdade nem sempre se cumpriu historicamente de uma maneira feliz: o seu percurso realiza-se de forma intrinsecamente humana, com os seus sucessos e os seus fracassos, com os seus excessos e omissóes e com os seus ímpetos, hesitaçóes e paradoxos.

Conviria recordar o que a este propósito nos diz Norberto Bobbio, quando sublinha que «historicamente, a falta de liberdade nasce continuamente do próprio sonho da liberdade». Em particular isso verificou-se sob as promessas de uma verdade libertadora que rapidamente acabou por se transformar numa nova prisão para o ser humano. Mill, na senda do que haviam feito já Milton e Voltaire, entre outros, sublinhou como as perseguiçôes não foram capazes de calar a expansão do Cristianismo. No entanto, a Igreja rapidamente se esqueceu disso mesmo e, uma vez no poder, tentou responder à dissidência religiosa e ao livre exercício da razão com os autos, que, desgraçadamente, se chamaram da fé, e com a tentativa de excomungar os caminhos do pensamento e da ciência. Agora, nas sociedades ditas pós-moralistas, em que o religioso se tornou um tanto démodé face aos discursos da 
ciência e do pensamento laico, Jónatas Machado vem mostrar-nos, a propósito do diferendo entre criacionistas e evolucionistas, como o discurso científico, outrora perseguido, também se pode facilmente transformar numa linguagem totalitarista, procurando extirpar da discussão pública outras racionalidades. E o sintoma revelado por esta discussão parece-nos tanto mais pertinente quanto falamos da pretensão das sociedades contemporâneas em abarcar todo o domínio da verdade possível e do discurso público aceitável. A tendência para reduzir o humano a uma dimensão estritamente racional projecta-se nos discursos dominantes da eficácia, da performatividade, do útil, do científico.

Esta problemática não deixa de estar presente na discussão proposta por Alexandre Franco de Sá quando, às tiranias da maioria, contrapóe o poder mobilizador das minorias de se sobreporem à vontade geral, através da manipulação dos discursos públicos, em especial das formas de representaçáo dos media. Assim, aos receios da ditadura da maioria, evocado por Mill e Tocqueville, Alexandre Sá contrapóe o poder das minorias que, fazendo uso da sua capacidade de mobilização, através dos media, são capazes de impor as suas lógicas não menos totalitárias, não obstante o carácter mais ou menos revolucionário do seu discurso. Vivemos essa realidade de forma radical com os fascismos europeus, capazes de transformarem os estados de desencanto dos povos relativamente à política e à sua própria história num campo sedento, onde a propaganda e a manipulação puderam penetrar fundo. A capacidade das minorias campearem o espaço público contemporâneo, recorrendo à sua capacidade de mobilização, através de um discurso atractivo para os media e a opinião pública, é uma questão tanto mais actual quanto falamos de sociedades descrentes da vida política. Com efeito, parafraseando, num outro contexto, Marylin Strathern, é necessário que náo nos deixemos arrastar na tentação de confundirmos propostas de novas liberdades, quando estamos perante velhas tiranias que apenas se tornaram demasiado familiares.

Esse talvez seja o grande perigo das sociedades modernas. Mas esse perigo apenas resulta do facto de o conformismo e da indiferença, que Stuart Mill denunciou, terem deixado às minorias mobilizadas o campo livre da discussão pública. A fragilização da discussão pública interpela-nos directamente sobre a forma como dignificamos o legado de Liberdade das geraçóes que nos antecederam e o modo como queremos ser relembrados pelas geraçôes vindouras. Por isso, talvez a questáo não esteja no poder mobilizador das minorias, mas na crise de valores das sociedades no seu conjunto.

Esse é talvez o verdadeiro sentido da expressão, frequentemente atribuída a Thomas Jefferson, mas que tomámos de um texto de John Dewey, segundo a qual o «preço da liberdade é a eterna vigilância». Esta frase não é, de todo, uma bela chave-de-ouro para um texto difícil de concluir. À luz das discussóes que aqui fazemos, assumimo-la como uma interrogação: na medida em que deixamos que o espaço público seja facilmente colonizado por processos de manipulaçáo de alguns, seremos suficientemente dignos da Liberdade, da nossa precária liberdade? 